\title{
Indonesian Geothermal Energy Potential as Source of Alternative Energy Power Plant
}

\author{
Puji Suharmanto ${ }^{*}$, Annisa Nor Fitria and Sitti Ghaliyah ${ }^{\mathrm{b}}$ \\ a Master Program in Geothermal Exploration Dept. of Physics Faculty Math \& Natural Science University of Indonesia, Jakarta \\ b.Dept. of Physics Faculty Math \& Natural Science State University of Jakarta, Jakarta
}

\begin{abstract}
Indonesia is known as the Ring of Fire, nearly about $40 \%$ world's geothermal potential located in Indonesia. About 252 geothermal sites in Indonesia spread following the path of volcanic formation which stretches from Sumatra, Java, Nusa Tenggara, Sulawesi, to Maluku. It has total potential of about 27 GWe. Geothermal energy as a renewable energy and environmentally friendly, this large potential needs to be upgraded the contribution to fulfill domestic energy need which is able to reduce Indonesia's dependence on fossil energy sources which are depleting. Potential for geothermal energy is expected to fulfill the target of developing geothermal energy to generate electricity through the Geothermal Power Plant of 6000 MWe in 2020.
\end{abstract}

Keywords: Geothermal Energy, Electrical Energy, Geothermal Power Plant

\footnotetext{
* Corresponding author: Tel: +62-857 68357069

E-mail: harmansuharmanto@gmail.com
} 


\section{Introduction}

Indonesia is geologically located at the confluence of three major tectonic plates, the Eurasian Plate, IndoAustralian and the Pacific, this geological conditions make a real contribution to the availability of geothermal energy in Indonesia. Observed from the appearance of geothermal energy in the surface per unit area, Indonesia fourth ranks in the world, even from high temperature variables, Indonesia second ranks. Making Indonesia has the largest geothermal potential in the world to save 40 percent of the world's geothermal resources. Manifestations of geothermal energy in Indonesia is not less than 252 locations spread across Sumatra, Java, Nusa Tenggara, Bali, Sulawesi to the Moluccas (satunegeri.com, 2013).

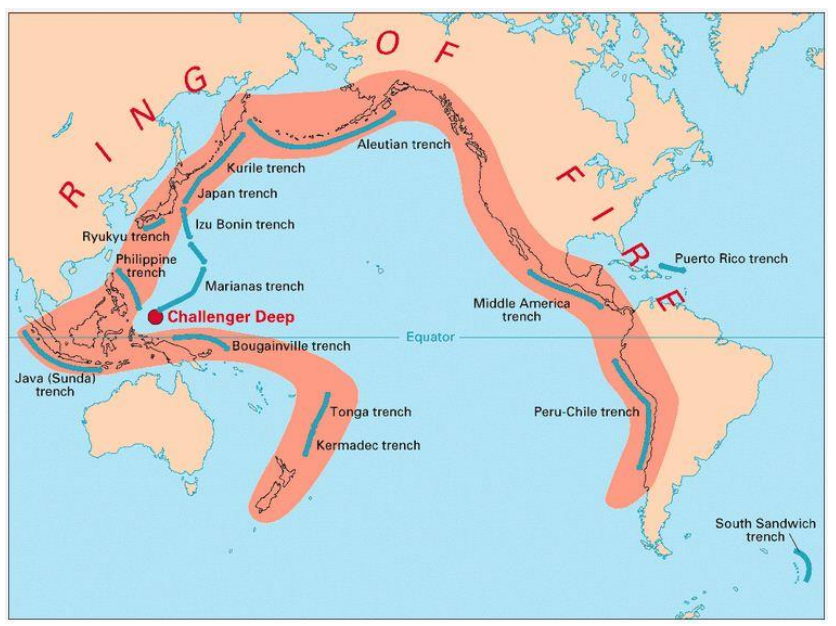

Fig. 1 Ring of fire expedition pathway in pasific (pubs.usgs.gov 2011)

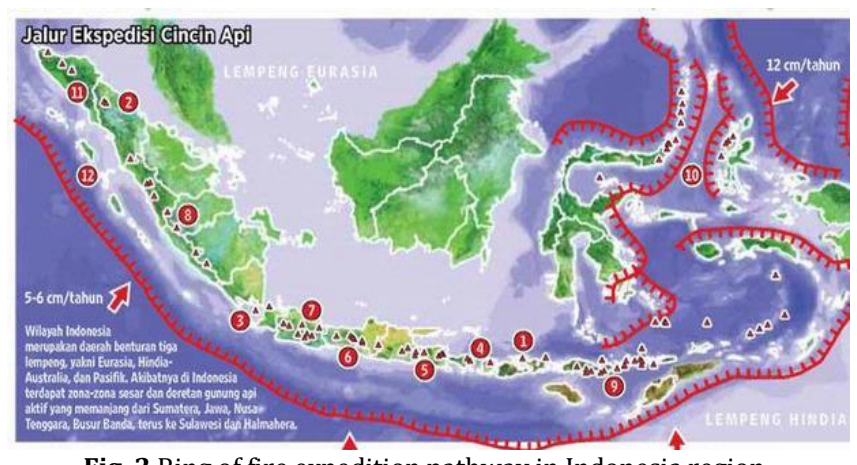

Fig. 2 Ring of fire expedition pathway in Indonesia region (travel.kompas.com 2011)
However in terms of development, Indonesia is still less than the United States and the Philippines. United States has a generating capacity of geothermal energy to the value of the largest installed 3,093 megawatts from $10.716,7$ MW of the world, followed by the Philippines with a value of 1,904 megawatts from 10.716,7 MW of the world, and Indonesia in the third, with 1,341 megawatts. Though Indonesia has a total potential of geothermal energy by 27-29 thousand megawatts spread across the region. Mean sequestered geothermal potential for electricity generation amounted to only $4.6 \%$ of the total potential.

On the other hand, the amount of fuel consumption in Indonesia reached 1.4 million barrels per day. National oil production is only 850 thousand barrels per day and the government ration is only about 540 thousand barrels per day. Incurred substantial imports, amounting to 900 thousand barrels per day to be imported (Solopos.com, 2013). Meanwhile for fuel subsidy in 2012 amounted to Rp 211.9 trillion and electricity subsidies of Rp 94.6 trillion, so total subsidy is very large, ie above Rp 300 trillion. Under conditions of fluctuating oil prices had reached $\$ 140$ per barrel, it is very burdensome government subsidy (national.contan.co.id, 2013). Therefore need to be encouraged alternative energy from new and renewable energy, one of them is geothermal energy.

Increasing importance of the role of new and renewable energy has long been recognized by the government. On January 25, 2006, the President set a Presidential Regulation No. 5 of 2006 on National Energy Policy. In the regulation, the government is targeting a national energy policy objectives in a form of realization of the optimal energy mix by 2025 the petroleum to less than $20 \%$, natural gas to more than $30 \%$, coal to more than $33 \%$, and the total of new and renewable energy to more than $17 \%$ with geothermal proportion of $5 \%$. In 2011, the proportion of geothermal energy in the national energy mix is still very small, amounting to only 1.33 percent (Pusdatin of Energy, 2012). 


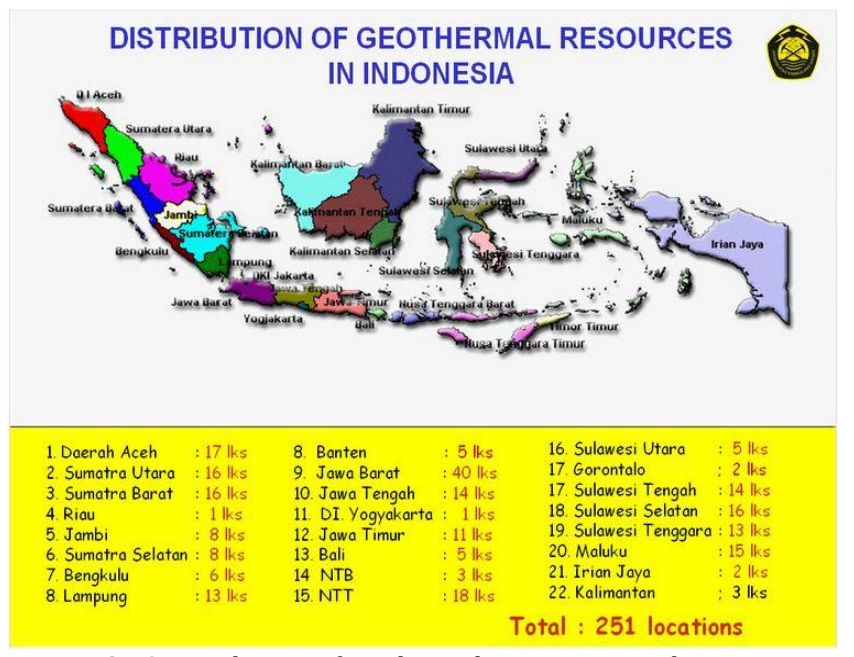

Fig. 3 Distribution of geothermal resources in indonesia (dtwh2.esdm.go.id 2011)

\section{Characteristics and Potential Geothermal Indonesia}

Most of the geothermal energy has been used throughout the world, energy is the energy extracted from the hydrothermal system, because the use of hotigneous systems and conduction-dominated systems require high-tech extraction. Hydrothermal system is closely related to the system and the formation of volcanoes volcanism at active plate boundary zone contained heat flow. Indonesia is located between three active plates, allowing the heat from the Earth's deep geothermal wells can be transferred to the surface with the fracture system. This makes Indonesia's strategic position as the richest country in geothermal hydrothermal systems scattered throughout the volcanic arc that most of the sources of geothermal energy in Indonesia has a high enthalpy which is suitable to utilize as generating geothermal energy of electricity.

Potential of geothermal energy in Indonesia is the largest in the world at around 40\% of the world's geothermal reserves. Estimated to be 219 million BOE, equivalent to $27.00 \mathrm{GW}$. This amount can be utilized for $2953.50 \mathrm{GWh}$ while the new installed capacity of 800.00 MW still.
Table 1.

National renewable energy potential ( source: Dept. ESDM, 2008)

\begin{tabular}{|c|c|c|c|c|}
\hline $\begin{array}{c}\text { KIND OF } \\
\text { RENEWBLE } \\
\text { ENERGY }\end{array}$ & RESOURCES & SUITED & UTILIZATION & $\begin{array}{l}\text { INSTALLED } \\
\text { CAPACITY }\end{array}$ \\
\hline WATER & $\begin{array}{l}\text { 845,00 BOE } \\
\text { Million }\end{array}$ & $75,67 \mathrm{GW}$ & $\begin{array}{c}6.851,00 \\
\text { GWh }\end{array}$ & $4.200,00 \mathrm{MW}$ \\
\hline $\begin{array}{c}\text { GEOTHERM } \\
\text { AL }\end{array}$ & $\begin{array}{l}\text { 219,00 BOE } \\
\text { Million }\end{array}$ & $27,00 \mathrm{GW}$ & $\begin{array}{c}2.953,50 \\
\text { GWh }\end{array}$ & 800,00 MW \\
\hline $\begin{array}{c}\text { MINI/MICR } \\
\text { O HYDRO }\end{array}$ & \multirow[t]{4}{*}{$\begin{array}{l}\text { 458,75 BOE } \\
\text { Million }\end{array}$} & $\begin{array}{c}\text { 458,75M } \\
W\end{array}$ & & 84,00 MW \\
\hline BIOMASS & & $49,81 \mathrm{GW}$ & & $302,40 \mathrm{MW}$ \\
\hline SOLAR & & $\begin{array}{c}\text { 4,80kWh/ } \\
\mathrm{m}^{2} / \text { day }\end{array}$ & & 8,00 MW \\
\hline WIND & & 9,29 GW & & $0,50 \mathrm{MW}$ \\
\hline $\begin{array}{c}\text { URANIUM } \\
\text { (NUCLEAR) }\end{array}$ & $\begin{array}{c}24.112 \\
\text { TON* E.Q. } \\
\text { GW TH) }\end{array}$ & & & \\
\hline
\end{tabular}

Approximately $80 \%$ geothermal sites in Indonesia with isolated active volcanic systems such as Sumatra (81 locations), Java (71 locations), Bali and Nusa Tenggara (27 locations), Maluku (15 locations) and North Sulawesi (7 locations) while those in in nonvolcanic environment that is active in Sulawesi (43 locations), Bangka Belitung (3 locations), Kalimantan (3 locations) and Papua (2 locations).

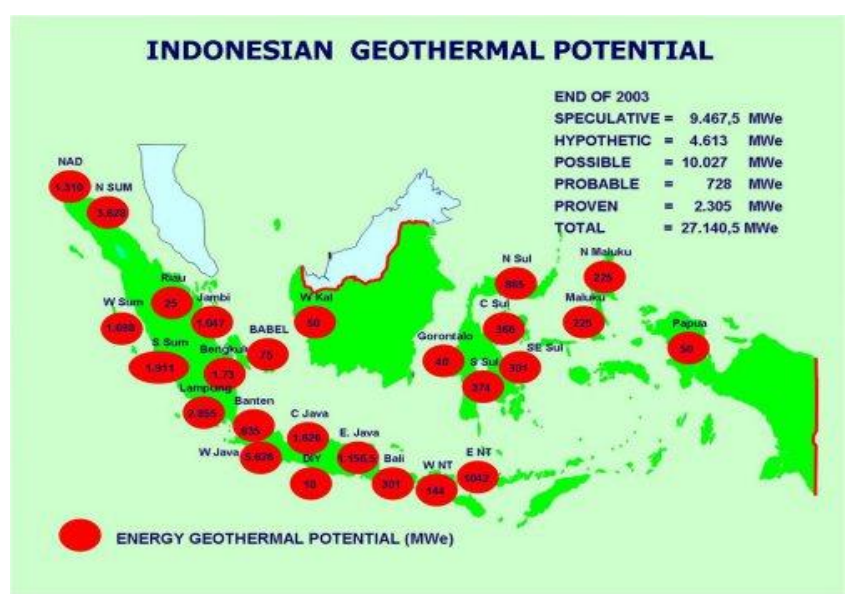

Fig. 3 Geothermal potential distribution map of Indonesia (source: indonesiamatters.com, 2012)

The total composition of the geothermal potential of 252 locations are $27357 \mathrm{MW}$ which is consisting of 14 007 MW of resources and reserves of 13,350 MW (source: Directorate of Mineral Resources Inventory). Data is dynamic potential will change every time in accordance with the level of exploration activities undertaken by both government and developers. 


\section{Geothermal Power Plant}

The working principle of geothermal power plant (PLTP) is almost similar to generator steam power, the heat emanating from the bowels of the earth directly used to turn a turbine generator to produce electrical energy. Hot steam that comes out is not directly used, but need to go through the process because the steam released screening still contain other ingredients such as water, mineral, salt. Hot rocks to produce steam to raise the water into the hot rocks in the bowels of the earth so that it becomes steam. The resulting steam is then purified and then used to turn turbines and generate electricity generator then transmitted.

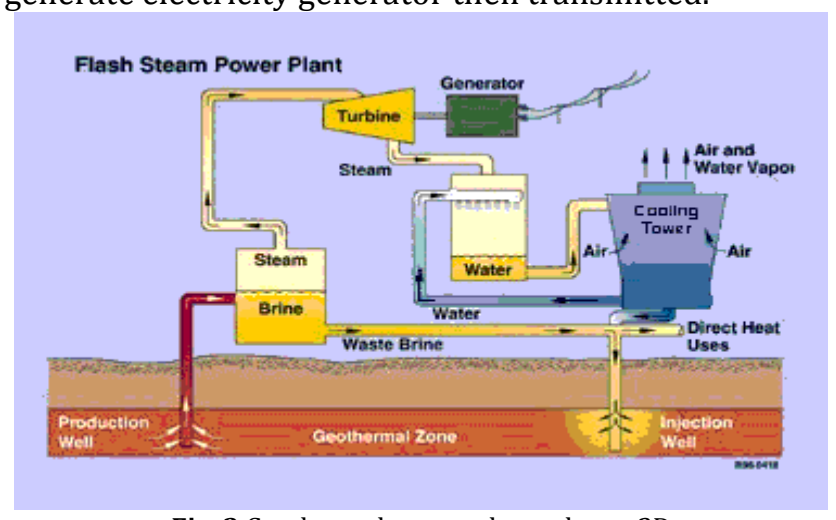

Fig. 3 Geothermal power plant scheme 2D (source: people.uwec.edu)

\section{Excellence Geothermal Power Plant.}

Geothermal energy is very feasible to be developed as it has many advantages, including the following:

1. This energy including green energy because the resulting $\mathrm{CO}_{2}$ emissions less than fossil energy.

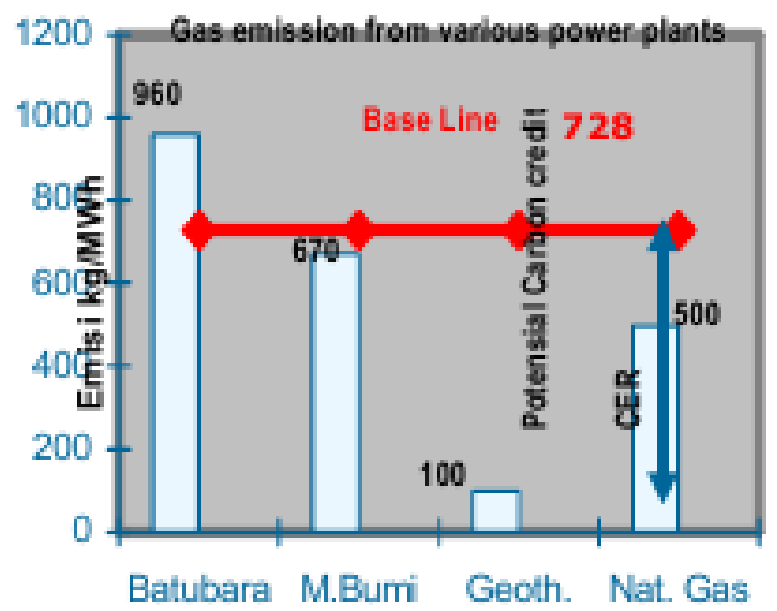

Fig. 4 Graphs $\mathrm{CO}_{2}$ gas emissions from various plant (source: digilib.its.ac.id/public/ITS-Undergraduate-94792207100532-Paper.pdf)

2. Geothermal development can preserve forests due to geothermal systems maintain the necessary balance of protection forest that serves as a catchment area.

3. Reliability of electric power generated from geothermal energy can be sustained in the long term (can be more than 30 years).

4. In general, the capacity factor of geothermal power generation in Indonesia could reach 90 percent per year, as an example of PLTP Kamojang 93\%, 94\% tiger puppet, and Darajat $93 \%$ so it can be used as base load in electricity systems.

5. Transport of geothermal resources is not affected by the risk of transportation because it does not use but only to use mobile transportation pipelines within a short distance.

6. Geothermal energy is available on an ongoing basis throughout the year. Productivity of geothermal resources relatively unaffected by climate change yearly. This is different from that affected hydropower annual season.

7. Utilization of geothermal energy does not require large tracts of land.

8. Geothermal energy can be used directly for power generation.

9. The price of electricity derived from geothermal is cheap enough for $\$ 7-10$ cents per kwh. The price is well below the price of electricity derived from fossil fuels amounting to $\$ 40-45$ cents per kwh.

10. The use of geothermal energy can save the dependence on fossil fuels is significant. As an illustration of geothermal comparison with the fuel as follows: $1 \mathrm{Kwh}$ generated electricity assumption requires 0:28 liter of fuel or $1 \mathrm{MWh}$ requires 280 liters or approximately 2 barrels. If Indonesia's geothermal potential of 20,000 MW in an hour then equal 5,600,000 liters or 35.223 barrels, in one day geothermal potential is $134,400,000$ liters or the equivalent of 845.351 barrels of fuel. In one year could save about $48,384,000,000$ liters or $304,326,214$ barrels.

11. Geothermal power is also not noisy and unreliable. 
12. Geothermal power plants produce electricity about $90 \%$, compared to $65-75 \%$ of fossilfueled power plants.

\section{Discussion and Summary}

Geothermal energy as a renewable and environmentally friendly, this large potential contribution needs to be upgraded to meet domestic energy needs to be able to reduce Indonesia's dependence on fossil energy sources are depleting. Potential for geothermal energy is expected to meet the target of developing geothermal energy to generate electricity through the Geothermal Power Plant (PLTP) in Indonesia.

Most of the total potential of $27 \mathrm{GW}$ of geothermal energy sources so it is possible to be used as a power plant. The requirement for electricity, especially in the eastern regions of Indonesia will be able to accelerate economic growth in particular areas. As an environmentally friendly energy sources and renewable, and nature cannot be exported, geothermal development is a very appropriate alternative to support national energy needs.

The resulting increase in electricity prices of geothermal power plants will stimulate investment interest assessed the geothermal developers. The price increase will increase the economic value of the geothermal plant project

Geothermal potential of more than 29 gigawatts electric (GWe), but the utilization of new 5 percent of the total potential. To encourage investments in geothermal, the government will raise the price of electricity produced geothermal power plant (PLTP) of 9.7 U.S. cents per kilowatt hour (kWh) to 10-17 U.S. cents per kWh with the tariffs vary between regions and islands

Currently renewable energy potential in Indonesia is less explored, but the potential is huge. Total potential of renewable energy investment reached 100 billion U.S. dollars. For geothermal energy, the potential investment projects about 3 billion U.S. dollars, it also covers all the existing geothermal potential.

The great potential of geothermal energy to face a number of challenges in its development. Challenges that must be overcome so that the great potential of geothermal energy can be utilized for the benefit of society. Here the necessary coordination of all parties, namely the government, employers, and society.

\section{Acknowledgements}

To Renewable Energy Physics Group (Mr. Muhamad Ihsan, Mrs. Sri Endang Wahyuni, S.Si, Mrs. Dhika Amelia, Mrs. Annisa Nor Fitria, Mrs. Sitti Ghaliyah), MRT Science Club, Executive Boarding Student Faculty Math \& Natural Science State University of Jakarta in 2013, then the master program in Geothermal Exploration Department of Physics, University of Indonesia in 2013.

\section{References}

Akbar, Eko. (2008) Tinjauan Energi Panas Bumi : Potensi, Peran, Dan Prospek Dalam Penyediaan Energi, PT Gramedia: Jakarta.

Astria, Reindy. (2013) KONSUMSI BBM: Kebutuhan Terus Meningkat, Impor Minyak Indonesia 2013 Bakal Membengkak, dari alamat web

http://www.solopos.com/2013/01/06/konsumsibbm-kebutuhan-terus-meningkat-impor-minyakindonesia-2013-bakal-membengkak-365108 diakses pada Sabtu, 29 Juni 2013 Pukul 15.30 WIB.

Edwards, L.M., Chilingar, G.V., Rieke III, H.H., Fertl, W.H. (1982) Handbook of Geothermal Energy, Gulf Publishing Company, Houston, Texas

EKTRO INDONESIA. (1996) Berbagai Insentif bagi Swasta :Tantangan dan Peluang Pembangunan Energi dan Tenaga Listrik Edisi ke lima,

EKTRO INDONESIA. (1996) Pengembangan Energi Terbarukan Sebagai Energi Aditif di Indonesia Edisi ke lima.

Indartoni, Y S. (2005) Krisis Energi di Indonesia: Mengapa dan Harus Bagaimana, INOVASI Online Edisi Vol. 05/XII/November http://io.ppijepang.org

Hilal, Samsul \& Marwan, Batubara. (2013) Masalah Pengembangan Energi Panas Bumi, dari alamt web http://satunegeri.com/masalah-pengembanganenergi-panas-bumi.html, diakses pada Jum'at, 28 Juni 2013 Pukul 14:12 WIB.

K.D, Herlina. (2013) Realisasi Subsidi BBM dan Listrik Membengkak, dari alamat web http://nasional.kontan.co.id/news/realisasi-subsidibbm-dan-listrik-membengkak, diakses pada Jum'at, 28 Juni 2013 Pukul 15.00 WIB 
Kebijakan Energi Nasional 2003 - 2020. Departemen Energi dan Sumber Daya Mineral.

Pedoman dan Pola Tetap Pengembangan Industri Ketenagalistrikan Nasional 2004-2020. Departemen Energi dan Sumber Daya Mineral.

Rancangan Pedoman dan Pola Tetap Pengembangan dan Pemanfaatan Energi Panas Bumi 2004 - 2020. Departemen Energi dan Sumber Daya Mineral.

Rancangan Road Map Pengembangan Panas Bumi 2004 - 2020. Departemen Energi dan Sumber Daya Mineral.

Saptadji, Nenny. (2008) Sekilas Tentang Panas Bumi. ITB: Bandung.

SNI 13-5012. (1998) Klasifikasi Potensi Energi Panas Bumi di Indonesia. Badan Standardisasi Nasional-Bs.

Sukarjaputra, Rakaryan. 25 Tahun Panas Bumi di Indonesia. Harian Kompas Senin, 14 Juli 2003
Wicaksono, Pebrianto Eko. (2013) Bangun PLTN Terbesar di Dunia, RI Hemat Subsidi Rp 3.5 triliiun, diakses pada Rabu, 11 April 2013, http://bisnis.liputan6.com 